JPBSI 9(1) (2020)
Jurnal Pendidikan Bahasa dan
Sastra Indonesia

\title{
PENINGKATAN KETERAMPILAN MENULIS TEKS CERITA IMAJINASI BER- MUATAN NILAI TOLERANSI MENGGUNAKAN MODEL COPY THE MASTER BERBANTUAN MEDIA FILM ANIMASI BAGI PESERTA DIDIK KELAS VII D SMP NEGERI 11 SEMARANG
}

\author{
Cintia Nugraha ${ }^{\bowtie}$ Mukh Doyin
}

Jurusan Bahasa dan Sastra Indonesia, Fakultas Bahasa dan Seni, Universitas Negeri Semarang, Indonesia

\section{Info Artikel}

Sejarah Artikel:

Diterima Oktober 2019

Disetujui Februari 2020

Dipublikasikan Mei 2020

\section{Keywords:}

Writing skills, Story

Imagination Text, Copy the

Master Model, Animated

Film and Tolerance Value

\begin{abstract}
Abstrak
Penelitian ini dilandaskan pada rendahnya keterampilan menulis cerita imajinasi pada peserta didik. Rendahnya keterampilan menulis cerita imajinasi tersebut disebabkan karena ketidaktepatan penggunaan model pembelajaran yang digunakan oleh pendidik membuat peserta didik kesulitan dalam mengembangkan ide, imajinasi dan daya kreativitasnya dalam menulis teks cerita imajinasi. Berdasarkan hal tersebut solusi yang dapat diterapkan yaitu penggunaan model copy the master berbantuan media film animasi sebagai upaya untuk meningkatkan keterampilan menulis teks cerita imajinasi bagi peserta didik. Solusi tersebut membuat daya imajinasi dan kreativitas peserta didik dapat tumbuh secara optimal, degan begitu peserta didik tidak lagi mengalami kebingungan untuk menulis teks cerita imajinasi. Hasil penelitian membuktikan adanya peningkatan keterampilan menulis teks cerita imajinasi bagi peserta didik. Penelitian menggunakan jenis penelitian tindakan kelas dengan berbasis pada pendekatan kuantitatif dan kualitatif. Data penelitian diambil dari observasi, angket, hasil tes dan catatan lapangan. Hasil menulis cerita imajinasi pada kegiatan prasiklus nilai rata-ratanya sebesar 24.6 dengan $0 \%$ ketuntasan. Kemudian pada siklus I, nilai rata-rata meningkat tajam menjadi 86.88 dengan ketuntasan $100 \%$ dan pada siklus II, nilai rata-rata semakin meningkat menjadi 90.1 dengan ketuntasan $100 \%$. Pada siklus I dan siklus II, peserta didik mendapatkan perolehan nilai jauh lebih baik dari kegiatan prasiklus dan pada siklus I serta siklus II, $100 \%$ peserta didik tuntas KKM.
\end{abstract}

\begin{abstract}
This study is based on the lack of students' imagination story writing skills. The low of imagination story writing skills was caused by the inaccuracy use of learning models used by educators makes it difficult for students in developing ideas, imagination, and their creativity in writing imagination story texts. Based on that problem, the solution that could be applied was the use of copy the master model assisted by animated film media as an effort to improve the imagination story writing skills for students. The solution makes the imagination and creativity of students can improve optimally, so that students no longer experience confusion in writing imagination story text. The results of the study prove that there is an improvement in imagination story writing skills for students. The research uses quantitative and qualitative approaches-based classroom action research. The research data was taken from observations, questionnaires, results of the tests, and note- taking. The average score of writing imagination story in the pre-cycle activities is 24.6 with $0 \%$ of completeness. Then in the first cycle, the average score increased sharply to 86.88 with 100\% of completeness, and in the second cycle, the average value increased to 90.1 with $100 \%$ of completeness. In cycle I and cycle II, students got much better score than pre-cycle activities, and in cycle I and cycle II, 100\% of students completed Minimum Completeness Criteria.
\end{abstract}

(C) 2020 Universitas Negeri Semarang

\footnotetext{
Alamat korespondensi:

Gedung B1 FBS Unnes

Kampus Sekaran, Gunungpati, Semarang, 50229

E-mail:407cintianugraha@gmail.com
} 


\section{PENDAHULUAN}

Pembelajaran Bahasa Indonesia pada hakikatnya meliputi empat aspek keterampilan berbahasa. Berdasarkan keempat keterampilan dasar berbahasa tersebut, keterampilan menulis merupakan keterampilan yang paling sulit diantara keempatnya karena menulis adalah proses koginitif yang sangat rumit (Sibarani, 2015), sejalan dengan hal tersebut (Arifa \& Doyin, 2015) menjelaskan bahwasanya menulis merupakan keterampilan produktif yang membutuhkan waktu yang panjang, selain itu (Nurgiyantoro, 2009) berpendapat pula bahwa aktivitas menulis merupakan suatu bentuk manifestasi kemampuan dan keterampilan berbahasa paling akhir dikuasai pelajar bahasa setelah kemampuan mendengarkan, berbicara, dan membaca. Berdasarkan hal tersebut dapat diambil kesimpulan bahwa menulis merupakan keterampilan berbahasa paling sulit. Salah satu jenis teks yang sulit untuk dibelajarkan dalam keterampilan menulis yakni teks cerita imajinasi. Teks cerita imajinasi merupakan cerita khayalan yang bersifat rekaan dan berasal dari daya kreativitas pengarang dalam menuangkan imajinnya pada teks cerita (Widuroyekti, 2016). Dibutuhkan wawasan, kemahiran dalam memilih diksi dan kecerdikan ketika menyusun kalimat agar menimbulkan kesan imaji menjadi salah satu alasan mengapa keterampilan menulis teks cerita imajinasi menjadi keterampilan yang paling sukar dalam pembelajaran Bahasa Indonesia. Selain itu peserta didik tidak pernah mendapatkan materi berkaitan dengan menulis cerita imajinasi yang baik dan benar (Kapitan, Harsiati, \& Basuki, 2018). Alasan ini yang menjadikan keterampilan menulis cerita imajinasi semakin tidak diminati peserta didik.

Kesulitan serupa peneliti alami berdasarkan penelitian di SMP Negeri 11 Semarang, yang menunjukkan bahwa keterampilan menulis peserta didik kelas VII D terutama pada keterampilan menulis sastra yaitu teks cerita imajinasi masih sangat memprihatinkan. Rendahnya keterampilan peserta didik ketika menulis teks cerita imajinasi tentu dilandasai oleh berbagai faktor yang memengaruhinya. Beberapa faktor tersebut diantaranya (1) ketidaktepatan penggunaan model pembalajaran yang dilakukan oleh pendidik membuat peserta didik menjadi bosan dan malas saat mengikuti pembelajaran, (2) rendahnya kreativitas pendidik dalam menyajikan pembelajaran menghambat pertumbuhan daya imajinasi peserta didik, (3) rendahnya penghargaan dan antusias peserta didik terhadap pembelajaran $\mathrm{Ba}$ hasa Indonesia. Beberapa faktor tersebut menyebabkan semakin sulitnya menulis teks cerita ima- jinasi dibelajarkan bagi peserta didik kelas VII D SMP Negeri 11 Semarang. Teks cerita imajinasi memang menjadi salah satu teks Bahasa Indonesia yang sulit untuk dibelajarkan, mengingat dibutuhkannya stimulus berupa daya imajinasi peserta didik dan ketepatan model pembelajaran serta cara pendidik dalam mengajar menjadi salah satu kunci penting untuk tercapaianya kompetensi dasar pembelajaran yang sesuai (Ratni, 2016).

Hasil penelitian yang dilakukan pada kelas VII D SMP Negeri 11 Semarang menunjukkan bahwa rata-rata nilai yang peserta didik peroleh dalam menulis teks cerita imajinasi masih sangat rendah dan hampir satu kelas nilainya dibawah KKM. Peserta didik SMP Negeri 11 Semarang kelas VII D yang berjumlah 32 orang, rata-rata hanya mampu mengarang 1 hingga 2 paragraf dalam waktu pembelajaran 50 menit, dengan hasil karangan masih sangat jauh dari yang diharapkan. Hasil tulisan terlalu singkat dan sederhana, cerita yang disajikan pun tidak dapat dikatakan sebagai cerita imajinasi, karena cerita yang dihasilkan secara keseluruhan belum memiliki imaji yang utuh, selain itu ketidakstrukturan penulisan mebuat teks cerita imajinasi yang dihasilkan peserta didik tidak memiliki alur yang runtut sehingga terkesan rancu serta sulit dimengerti. Peserta didik mengeluh tidak memiliki ide saat menulis, sulit menentukan tema cerita dan bingung saat proses pembuatan teks cerita imajinasi. Hal ini yang membuat nilai menulis teks cerita imajinasi peserta didik sangat rendah. Nilai tertinggi yang peserta didik dapatkan yaitu 60 diperoleh 2 peserta didik, sedangkan 30 peserta didik lainnya nilai berkisar antara 0-50. Tentu hasil yang diharapkan bukan demikian, kompetensi yang harus dicapai sangat berbeda jauh dengan hasil pekerjaan peserta didik kelas VII D. Rendahnya nilai pembelajaran menulis teks cerita imajinasi ternyata sudah terjadi kurang lebih 2 tahun dihitung sejak pengimplementasian kurikulum 2013 revisi 2017.

Pada pembelajaran kurikulum 2013 tidak hanya menekankan aspek pengetahuan dan keterampilan peserta didik terhadap suatu materi pembelajaran yang diajarkan. Hal yang lebih penting dari aspek tersebut yakni sikap keseharian peserta didik. Perlu kita sadari bahwa semakin bertambahnya usia suatu generasi maka semakin tipis pula sikap santun yang dimiliki oleh generasi tersebut (T. S., 2006). Permasalahan serupa juga terjadi ketika peneliti melakukan pengamatan pada kelas VII D, rata-rata sikap toleransi antar peserta didik sangat rendah. SMP Negeri 11 Semarang merupakan salah satu sekolah yang pe- 
serta didiknya berasal dari berbagai kelas sosial yang berbeda. Hal tersebut yang mengakibatkan terjadinya kesenjangan dalam berbagai aspek diantaranya dalam aspek agama, pertemanan dan pembelajaran. Fakta yang peneliti temukan, pada kelas VII D yang terdiri atas 32 peserta didik tersebut 13 diantara 16 peserta didik perempuan tidak mengenakan kerudung. Perbedaan ini yang selalu membuat antar peserta didik saling berdebat, mereka saling mencemooh satu sama lain, perihal islam namun tidak mengenakan kerudung. Mereka menganggap peserta didik yang tidak mengenakan kerudung merupakan anakanak yang tidak patuh. Sedangkan peserta didik yang tidak mengenakan kerudung menganggap peserta didik yang mengenakan kerudung merupakan anak-anak desa yang tidak mengerti tentang fashion dan menganggap mereka anak-anak miskin. Akibatnya peserta didik yang merasa terpojokkan kemudian membalasnya dengan menghina orang tua, menggunakan nama panggilan orang tua atau mencemooh pekerjaan orang tua.

Berdasarkan hasil paparan tersebut, dapat diambil kesimpulan bahwa sebenarnya, pendidik dan peserta didik sangat membutuhkan model pembelajaran yang kreatif dan inovatif untuk pembelajaran menulis teks cerita iamjinasi sekaligus untuk meningkatkan sikap toleran antar peserta didik. Model pembelajaran copy the master berbantuan media film animasi untuk meningkatkan keterampilan menulis teks cerita imajinasi bermuatan nilai toleransi menjadi solusi yang tepat bagi peserta didik kelas VII D SMP Negeri 11 Semarang. Model copy the master sederhana dalam penerapannya namun inovatif dan mudah bagi pendidik maupun peserta didik dalam proses pembelajaran. Peserta didik Kelas VII D lebih tertarik dalam mengikuti proses pembelajaran menulis teks cerita imajinasi, karena disajikan dengan menyenangkan dan penuh dengan stimulus-stimulus yang membuat daya kreativitas mereka menjadi meningkat. Model copy the master merupakan salah satu model yang paling dekat dengan penulis (Kurnianingtyas, 2015). Pemilihan model copy the master pada pembelajaran menulis cerita imajinasi juga didasarkan pada keberhasilan penelitian-penelitian terdahulu yang menerapkan model copy the master dalam pembelajaran menulis cerita, diantaranya (1) Penerapan Model Copy The Master Berbasis Perkembangan Intelektual dalam Pembelajaran Menulis Berita Kelas VII pada tahun 2013 (Nursayyidah, 2015), penelitian ini menggunakan model yang serupa dengan peneliti namun berbeda pada jenis teks yang digunakan, (2) Peningkatan Keterampilan Menulis Menggunakan Teknik Copy The Master
Pada Mahasiswa Bahasa Sastra Indonesia STKIP Rokania (Putri, 2017), (3) Pengaruh Teknik Copy The Master Terhadap Keterampilan Menulis Teks Prosedur Siswa Kelas VII MTsN Lubuk Buaya Kota Padang (Zurita, Effendi, \& Catri, 2017). Sementara itu, pemilihan media film animasi turut didasarkan pada keberhasilan penelitian-penelitian terdahulu yang teruji mampu meningkatkan hasil belajar peserta didik, diantaranya (1) Effects Of The Use Of Animation Film Media On The Narrative Text Writing Skill Of Grade V Students Of Ess (Astuti \& Mustadi, 2014), (2) Pengaruh Pemanfaatan Media Pembelajaran Film Animasi Terhadap Hasil Belajar (Rahmattullah, 2011) dan (3) Learning Implementation Of Fantasy Stories Text In The Seventh F Of Smp Negeri 8 Yogyakarta (Najmi, 2015). Penguatan nilai toleransi pada model ini, peneliti harapkan akan menjadikan sebuah landasan bagi dasar pemikiran peserta didik kelas VII D. Pendidikan nilai karakter yang kuat melalui penerapan model dengan bermuatan nilai toleransi akan melatih peserta didik untuk memiliki pemikiran dan perilaku yang baik. Penguatan nilai karakter yang baik akan memengaruhi karakter seseorang hingga dewasa (Hakim, 2012). Pendidikan karakter yang efektif dibangun dari iklim sekolah yang kondusif untuk berkembangnya karakter yang positif (Mulyatiningsih, 2010).

\section{METODE PENELITIAN}

Penelitian ini merupakan jenis penelitian tindakan kelas. Pendekatan yang digunakan merupakan pendekatan campuran yakni kuantitatif dan kualitatif. Penelitian Tindakan Kelas yang dilakukan peneliti memiliki tujuan untuk meningkatkan keterampilan berbahasa pada aspek menulis teks cerita imajinasi bermuatan nilai toleransi dengan menggunakan model copy the master berbantuan media film animasi. Alur penelitian menggunakan desain model spiral oleh Kemmis dan Mc. Taggart, dengan 4 tahapan yakni (1) perencanaan, (2) pelaksanaan, (3) pengamatan dan (4) refleksi. Penelitian yang dilakukan oleh peneliti sebanyak 2 siklus dengan siklus I terbagi atas 3 pertemuan dan siklus II terbagi atas 2 pertemuan.

Penelitian tindakan kelas yang dilakukan menghasilkan 2 jenis data yakni jenis data kuantitatif dan kualitatif. Kedua jenis data tersebut diperoleh dari tes, observasi, wawancara, angket dan catatan lapangan.

Penelitian ini dilaksanakan di SMP Negeri 11 Semarang. J1. Karangrejo Tengah, Karangrejo, Kecamatan Gajahmungkur, Kota Semarang, Jawa Tengah. Lebih spesifik penelitian ini dilakukan di kelas VII D SMP Negeri 11 Semarang. Ada beberapa alasan mengapa SMP Negeri 11 Se- 
marang dipilih sebagai tempat penelitian. Alasan pertama, berdasarkan hasil observasi mengenai proses pembelajaran ditemukan ketidaksesuaian antara model pembelajaran dengan hasil yang diterapkan, kedua SMP Negeri 11 Semarang adalah salah satu SMP dengan kualitas belajar dalam kategori menengah ke bawah, berdasarkan dari hal tersebut peneliti berusaha meningkatkan hasil belajar peserta didik utamanya pada menulis teks cerita imajinasi bermuatan nilai toleransi. Terakhir, peneliti memilih SMP Negeri 11 Semarang, karena berdasarkan informasi dari pendidik, belum ada penelitian sejenis mengenai penerapan model pembelajaran copy the master berbantuaan media film animasi, sehingga diharapkan tidak ada penelitian ganda.

\section{HASIL PENELITIAN DAN PEMBAHASAN}

Hasil penelitian yang dipaparkan meliputi tiga hal, yaitu (1) proses pembelajaran keterampilan menulis teks cerita imajinasi bermuatan nilai toleransi melalui penggunaan model copy the master berbantuan media film animasi, (2) peningkatan keterampilan menulis teks cerita imajinasi bermuatan nilai toleransi setelah diterapkannya model copy the master berbantuan media film animasi dan (3) perubahan sikap peserta didik setelah diterapkannya model copy the master berbantuan media film animasi.

\section{Proses pembelajaran keterampilan menulis teks cerita imajinasi bermuatan nilai toleransi melalui penggunaan model copy the master ber- bantuan media film animasi.}

Pada bagian pembahasan peneliti memaparkan hasil dari proses pembelajaran siklus I dan siklus II pembelajaran menulis teks cerita imajinasi bermuatan nilai toleransi dengan model copy the master berbantuan media film animasi. Siklus I terbagi menjadi 3 pertemuan dan siklus II terbagi menjadi 2 pertemuan. Proeses pembelajaran siklus I pada pertemuan 1 sebelum masuk pada kegiatan pembelajaran inti, terlebih dahulu pendidik memberikan gambar film Upin Ipin dan Doraemon untuk mengalihkan perhatian peserta didik, kemudian diselipkan cerita motivasi, cerita motivasi tersebut erat kaitannya dengan nilai toleransi, hal ini bertujuan agar peserta didik terstimulus dan mengerti terlebih dahulu terkait arti pentingnya nilai toleransi dalam kehidupan. Pada kegiatan apersepsi ini, pendidik juga memberikan nasihat-nasihat bagi peserta didik agar menjadi anak yang pintar berguna bagi bangsa dan negara. Selanjutnya kegiatan pembelajaran masuk pada pembelajaran inti yang terdiri atas penjelasan materi terkait cerita imajinasi, yang terdiri atas struktur teks cerita imajinasi, unsur teks cerita imajinasi, kaidah kebahasaan cerita imajinasi dan nilai toleransi yang wajib ada dalam setiap cerita imajinasi. Nilai toleransi wajib hadir dalam setiap cerita imajinasi tujuannya agar peserta didik dapat menggali sendiri nilai-nilai toleransi yang pernah mereka rasakan dan mereka lihat dalam kehidupan peserta didik. Selanjutnya setelah semua materi tersamapaikan, langkah selanjutnya yaitu peneliti memutarkan tayangan film animasi yang berjudul "Upin Ipin Metrobot". Pada kegiatan pembelajaran I ini, sedikit banyak peserta didik sudah lebih tenang dan kooperatif dalam kegiatan pembelajaran. Ketika peneliti menjelaskan, peserta didik pun mendengarkan dengan tenang. Pada kegiatan pembelajaran I setelah semua tahapan terselesaikan, pada akhir pembelajaran peneliti menjelaskan terkait langkah pembelajaran yang akan dilaksanakan pada pertemuan selanjutnya, sehingga peserta didik harus terlebih dahulu banyak belajar dan banyak membaca terkait cerita imajinasi. Selanjutnya pada pertemuan II, peserta didik kembali diputarkan film animasi yang sama seperti pada pertemuan I, tujuannya agar peserta didik bisa menyegarkan ingatannya kembali terkait film animasi yang diputarkan kemarin. Pada pertemuan II inti pembelajaran peserta didik terfokus pada menulis cerita imajinasi. Awalnya peserta didik dibentuk berkelompok sesuai dengan ketentuan peneliti, dengan hitungan 10 peserta didik kemudian saling berkelompok sesuai dengan anggota yang telah ditentukan oleh peneliti. Tujuan dibentuk kelompok, sebagai pembuktian bahwa antar peserta didik bisa saling toleransi utamanya toleransi berpendapat dalam kegiatan pembelajaran. Selain itu agar tidak terjadi lagi kesenjangan dan saling mengejek antara peserta didik yang berkerudung dan tidak berkerudung. Dibentukanya kelompok membuat mereka secara langsung harus benar-benar bisa berkomunikasi dengan baik dengan antar peserta didik, hasil akhirnya mereka secara bersama-sama mampu untuk menulis teks cerita imajinasi bermuatan nilai toleransi. Tidak berhenti pada itu saja, peneliti memiliki peran yang sangat penting selain sebagai fasilitator juga sebagai mediator bila ada kelompok yang saling mengukuhkan pendapatnya. Peneliti selalu berkeliling pada kelompokkelompok peserta didik agar peneliti mengetahui kesulitan dan hal apa yang sekiranya bisa peneliti bantu selama proses menulis cerita imajinasi. Pada pertemuan II siklus I ini ada satu hal yang diluar rencana peneliti, yakni ditengah pembelajaran ada pengumuman terkait jam pembelajaran yang dikurangi karena sekolah akan melakukan 
sosialisasi terkait rencana akreditasi sekolah. Waktu menulis yang seharusnya 60 menit atau 1 jam, berubah hanya menjadi 45 menit. Sehingga dengan kondisi waktu yang sangat terbatas tersebut, peserta didik dalam kelompok harus benar-benar saling bekerjasama untuk menyelesaikan cerita imajinasi. Pada mulanya peneliti merasa ragu dan sempat takut bila peserta didik tidak dapat menyelesaikan cerita imajinasinya, namun keraguan tersebut sirna ketika satu persatu perwakilan kelompok menyerahkan hasil kerjanya tepat saat bel pergantian pembelajaran berbunyi. Peserta didik justru semakin antusias ingin membuat cerita imajinasi lagi secara individu, agar cerita yang mereka buat bisa dari hasil pemikiran dan ide kreatif mereka sendiri. Siklus I diakhir dengan pembelajaran pertemuan ke 3. Pada pertemuan ke-3 peserta didik dibentuk kembali kedalam kelompok-kelompok seperti pada pertemuan sebelumnya, pada pertemuan 3 kegiatan inti pembelajaran adalah tahapan menyunting cerita imajinasi yang telah dibuat oleh peserta didik secara bekelompok. Namun sebelumnya peneliti terlebih dahulu memberikan ulasan terkait cerita imajinasi yang telah dibuat oleh masing-masing kelompok. Ulasan ini diberikan agar peserta didik mengerti pada bagian apa yang harusnya lebih ditonjolkan di dalam cerita, sudah sesuaikah dengan alur cerita dan sudah ada atau belum nilai toleransi di dalam cerita. Kemudian peneliti menjelaskan secara sekilas terkait alur cerita, unsur beserta nilai toleransi dalam cerita imajinasi, baru setelah semuanya selesai peneliti membagikan hasil tulisan cerita imajinasi peserta didik untuk disunting bersama kelompok. Pada tahapan menyunting, peneliti mendampingi masing-masing kelompok secara bergantian, tujuannya agar bila dirasa masih ada hal yang ingin ditanyakan peserta didik tidak lagi merasa kesulitan dan kebingungan untuk menemukan solusinya. Pertemuan III siklus I diakhiri dengan pengumpulan hasil cerita imajinasi dan pemberian hadiah bagi kelompok yang mendapatkan nilai tertinggi. Kelompok yang mendapatkan hadiah hanya ada 1 kelompok, dengan perolehan nilai sebesar 93. Pemberian hadiah bertujuan agar memacu rasa bersaing antar peserta didik untuk berlomba-lomba secara positif mendapatkan hasil yang baik dalam kegiatan pembelajaran menulis cerita imajinasi bermuatan nilai toleransi dengan model Copy The Master berbantuan media film animasi.

Berbeda halnya dengan proses pembelajaran siklus I yang terdiri atas 3 pertemuan, pada siklus II proses pembelajaran hanya terdiri atas 2 pertemuan saja. Hal tersebut karena pada siklus I peserta didik terlebih dahulu harus dijelaskan terkait struktur, unsur, kebahasaan dan nilai toleransi dalam cerita imajinasi, sedangkan dalam siklus II hanya terbagi menjadi 2 pertemuan untuk kegiatan menulis teks cerita imajinasi pada pertemuan pertama dan kegiatan menyunting isi teks cerita imajinasi pada pertemuan kedua. Sama hal nya dengan siklus I, sebelum peserta didik diminta untuk menulis teks cerita imajinasi, terlebih dahulu peserta didik diberikan tayangan film animasi berjudul "Doraemon Lampu Pendeteksi Keinginan" untuk merangsang imajinasi dan kreativitas peserta didik dalam menulis teks cerita imajinasi. Siklus II peserta didik bekerja mandiri artinya tidak ada kegiatan diskusi kelompok saat menulis teks cerita imajinasi, kegiatan menulis dan menyunting dilakukan secara individu. Hal ini berlandaskan pada siklus I, banyak peserta didik yang mengeluh karena daya kreativitasnya tidak bisa dituangkan secara maksimal melalui cerita imajinasi yang dikerjakan bersama-sama dalam kelompok. Mereka harus saling berbagi ide dan mereka juga harus bermusyawarah terlebih dahulu sebelum menentukan jalan cerita. Maka dari itu pada siklus II, proses menulis cerita imajinasi dilakukan secara individu agar peserta didik dapat lebih leluasa menuangkan ide-ide kreativnya dalam menulis cerita imajinasi tanpa dibatasi dengan ide dan pendapat lain. Hal selanjutnya yang membedakan siklus I dan siklus II, waktu proses menulis cerita imajinasi, bila pada siklus I waktu yang diberikan terbatas hanya sekitar 45 menit, dalam proses pembelajaran siklus II waktu yang diberikan lebih lama yaitu sekitar 60 menit. Sehingga proses menulis cerita imajinasi peserta didik lebih lama, peserta didik memiliki kesempatan yang lebih luas untuk mengembangkan imajinasi dan daya kreativitasnya untuk dituangkan dalam bentuk cerita. Melihat antusiasme dan semangat peserta didik yang tinggi dalam menulis cerita imajinasi membuat peneliti semakin yakin bahwa hasil yang nantinya akan diperoleh peserta didik lebih baik dan lebih optimal dari siklus I. Pertemuan pertama diakhiri dengan pengumpulan hasil tulisan cerita imajinasi peserta didik dan penyampaian langkah pembelajaran selanjutnya yang akan dilakukan pada pertemuan kedua.

Pada pertemuan kedua, inti pembelajaran yang dilakukan yaitu menyunting teks cerita imajinasi. Sebelum peserta didik melakukan kegiatan menyunting, peserta didik terlebih dahulu diberikan ulasan singkat terkait hasil menulis mereka untuk kemudian diberikan saran secara umum yang membantu peserta didik dalam proses menyunting hasil tulisan cerita imajinasi mereka. Se- 
telah dijelaskan dan diberikan arahan serta saran, hasil menulis peserta didik kemudian dibagikan dan dilanjutkan dengan proses penyuntingan. Sama halnya dengan pembelajaran sebelumnya, peneliti bertindak sebagai fasilitator yang selalu berkeliling untuk memantau proses kerja peserta didik dan bila sewaktu-waktu ada peserta didik yang membutuhkan penjelasan peneliti bisa langsung memberikan solusi bagi kesulitan peserta didik. Proses pembelajaran kedua siklus II diakhiri dengan pengumpulan hasil tulisan cerita imajinasi peserta didik dan pemberian hadiah bagi peserta didik dengan nilai tertinggi. Ada sebanyak 5 anak dengan nilai 96 yang mendapatkan hadiah dari peneliti sebagai ucapan selamat sekaligus terima kasih peneliti.

\section{Peningkatan keterampilan menulis teks cerita imajinasi bermuatan nilai toleransi setelah diterapkannya model copy the master berban- tuan media film animasi.}

Hasil menulis cerita imajinasi peserta didik pada siklus I mengalami peningkatan yang cukup drastis bila dibandingkan dengan hasil menulis cerita imajinasi peserta didik pada prasiklus. Nilai terendah pada kegiatan menulis cerita imajinasi prasiklus adalah 0 sedangkan pada siklus 1 nilai terendah peserta didik adalah 83. Sedangkan nilai tertinggi peserta didik pada prasiklus hanya sampai pada nilai 60 pada siklus I nilai tertinggi peserta didik dapat mencapai 93. Secara keseluruhan nilai menulis cerita imajinasi peserta didik pada siklus I nilai paling rendah yaitu 83 dengan jumlah persentase (12.5\%) sebanyak 4 peserta didik. Selanjutnya nilai 84 dengan perolehan yang sama sebesar (12.5) dengan jumlah 4 peserta didik. Nilai yang sering muncul adalah 86 diperoleh 10 anak dengan persentase (31.2\%), nilai 87 diperoleh oleh 5 peserta didik dengan persentase $(15.6 \%)$, nilai 88 diperoleh 4 peserta didik dengan persentase (12.5\%), dan nilai tertinggi adalah 93 yang diperoleh 5 anak dengan persentase $(15.6 \%)$.

Pada proses menulisnya, tahapan siklus 1 proses menulis dilakukan secara berkelompok dengan tujuan untuk menguatkan nilai toleransi antar peserta didik, selain itu diharapkan dengan adanya kelompok-kelompok yang heterogen membuat peserta didik dapat berinteraksi dan lebih menghargai satu sama lain saat menulis cerita imajinasi. Pada siklus 1, hasil nilai peserta didik yang paling rendah adalah 83. Perolehan nilai tersebut merupakan perolehan nilai yang paling rendah, karena ada beberapa kriteria pada cerita imajinasi yang dihasilkan mendapatkan poin yang kurang maksimal. Selanjutnya untuk nilai tertinggi yaitu 93. Nilai tersebut merupakan nilai yang paling baik diantara kelompok-kelompok lain. Dalam proses pengerjaannya kelompok ini merupakan kelompok yang paling mandiri, dari segi penentuan tema sampai pada proses akhir pembuatan cerita, kelompok ini dapat berjalan sendiri sesuai dengan keinginan dan daya kreativitas bersama. Ini juga yang membuat nilai kelompok menjadi tinggi. Selain itu beberapa aspek penilaian juga memberikan pengaruh, diantaranya penentuan kejelasan tema, peserta didik dalam kelompok memiliki persamaan ide untuk membuat sebuah cerita dengan tema "Kepahlawanan". Tema tersebut diangkat dengan berbagai pertimbangan bersama, selain itu 3 dari 5 peserta didik dalam kelompok terinspirasi dari film Upin Ipin yang ditayangkan. Penilaian selanjutnya dari aspek penokohan, tokoh yang dihadirkan memiliki karakter yang kuat, selain itu pemberian bumbu-bumbu cerita menjadikan tokoh terlihat unik dan istimewa. Terkait latar, pada cerita imajinasi yang dihadirkan menggunakan latar masa depan, namun peserta didik mampu membuat cerita seolah-olah mereka dapat merasakan yang terjadi pada masa depan, sehingga cerita yang dihasilkan menarik dan unik. Berkaitan dengan latar, penyajian alur yang rapi dan runtut membuat cerita semakin mudah dimengeri meskipun memiliki latar dan dimensi waktu pada masa depan. Penggunaan beberapa diksi yang tepat, kata ganti indra dan keterkejutan yang sesuai memberikan nilai lebih dari cerita imajinasi yang ditulis. Terakhir, nilai toleransi yang dihadirkan memang belum sepenuhnya kritis, namun nilai yang ada memberikan kesan yang begitu baik dalam kesatuan cerita imajinasi yang peserta didik hadirkan. Hasil cerita imajinasi yang ditulis peserta didik dalam kelompok. Hasil tersebut merupakan hasil cerita imajinasi dengan perolehan nilai tertinggi diantara kelompok-kelompok lain.

Pemaparan hasil siklus I telah dirinci pada pembahasan sebelumnya. Hasil yang diperoleh peserta didik sudah sangat meningkat bila dibandingkan dengan prasiklus. Namun meski demikian tetap ada beberapa kendala dan kekurangan dalam pembelajaran pada siklus I. Diantaranya pemotongan waktu pembelajaran, pengerjaan secara kelompok membuat imaji dan kreativitas peserta didik harus terbagi dan beberapa kendala eksternal lainnya. Maka dari itu pada siklus II dirancang dan disusun secara lebih matang serta optimal, dengan tujuan menghasilkan nilai peserta didik yang jauh lebih dari pada siklus 1 .

Hasil perolehan menulis cerita imajinasi peserta didik pada siklus II juga meningkat, hanya saja ada 1 peserta didik yang mendapat ni- 
lai 81. Padahal pada siklus I nilai terendah adalah 83. Namun meski demikian nilai tertinggi tetap ada peningkatan, yang awalnya nilai tertinggi pada siklus I adalah 93, pada siklus II nilai tertingginya adalah 96. Untuk lebih rinci terlebih dahulu akan dipaparkan perolehan hasil peserta didik pada siklus II pembelajaran menulis cerita imajinasi dengan model copy the master berbantuan media film animasi bagi peserta didik kelas VII D SMP 11 Semarang. Nilai paling rendah yaitu 81 dengan jumlah persentase (3.1\%). Selanjutnya nilai 83,84 dan 92 dengan perolehan yang sama sebesar (3.1\%) dengan jumlah masing-masing 1 peserta didik. Kemudian nilai 85 dan 90 dengan persentase $(6.2 \%)$ dengan jumlah masing-masing 2 peserta didik. Nilai 86 dan 93, sejumlah 4 peserta didik denga persentase (12.5\%). Kemudian nilai 86, 88 dan 96 dengan jumlah peserta didik sebesar 5 anak dan persentase (15.6\%) serta yang terakhir 95 dengan jumlah peserta didik 3 anak dan persentase $(9.4 \%)$.

Berdasarkan paparan tersebut, bila dibuat perbandingan kegiatan prasiklus, siklus I dan siklus II. Hasil pada siklus II merupakan yang paling baik, dengan nilai tertinggi 96 dan nilai terendah adalah 81. Adanya peningkatan nilai dari peserta didik dan peningkatan nilai tertinggi menjadikan siklus II dikatakan lebih meningkat dari siklus I yang juga telah mengalami peningkatan pada kegiatan prasiklus. Untuk lebih jelas dan rinci, akan dipaparkan melalui diagram 4 .5berikut.

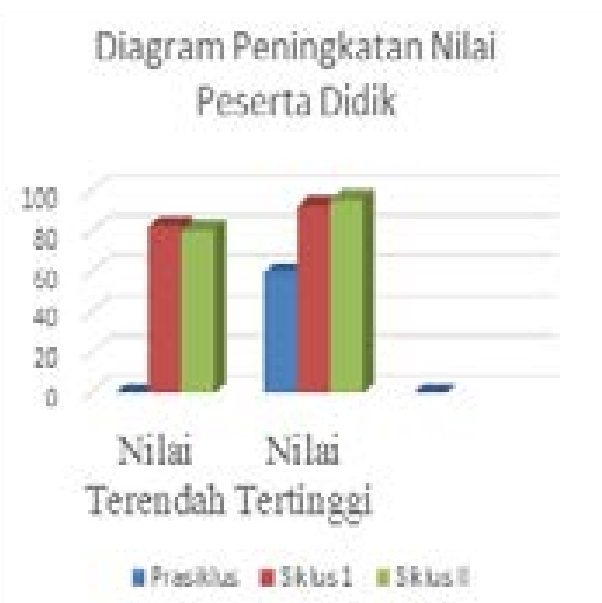

4.5 Diagram batang hasil peningkatan nilai peserta didik (prasiklus $\rightarrow$ siklus I $\rightarrow$ siklus II)

Berdasarkan diagram tersebut dapat dilihat peningkatan nilai peserta didik, nilai terendah dan nilai tertinggi. Nilai terendah peserta didik pada siklus I mengalami peningkatan yang pada prasiklus 0 menjadi 83 dan pada siklus II mengalami penurunan menjadi 81 . Kemudian nilia tertinggi prasiklus 60 , meningkat pada siklus I menjadi 93 dan pada siklus II menjadi 96. Pada siklus II, nilai terendah yaitu 81 yang diperoleh 1 peserta didik. Selanjutnya nilai tertinggi pada siklus II yaitu 96, diperoleh 5 peserta didik. Nilai tersebut salah satunya berasal dari cerita berjudul "Avangers Endgame" cerita imajinasi ini memiliki tema kepahlawanan. Mendapatkan nilai yang tinggi karena pada prosesnya, peserta didik sangat mengerti apa yang akan ditulis, jalan cerita sampai pada diksi apa yang ingin ia gunakan tanpa ragu sedikit pun ia berkreativitas. Berkaitan dengan cerita yang dihadirkan alur ceritanya pun runtut, latar yang digunakan juga sangat menarik yaitu latar masa kini namun dibalut dengan kehidupan di masa depan. Keunikan tokoh-tokoh yang dihadirkan sangat rinci dan karakter yang ditampilkan yaitu karakter-karakter superhero kuat dan cerdas seperti Iron Man atau yang sering dikenal dengan Tony Stark. Selain itu penggunaan diksi yang menarik dan cukup bervariatif, penggunaan diksi pencecap panca indra yang sesuai, urutan waktu yang tepat dan runtut membuat cerita terkesan begitu rapi dan menarik. Hanya saja kekurangannya terletak pada ungkapan keterkejutan yang kurang kuat sehingga peserta didik kurang bis untuk mendapatkan hasil yang maksimal. Terakhir berkaitan dengan nilai toleransi sudah baik namun lagi-lagi kurang kritis padahal bila dikembangkan bisa lebih baik dan lebih bagus lagi.

\section{Perubahan sikap peserta didik setelah diterap- kannya model copy the master berbantuan media film animasi.}

Pada kegiatan pembelajaran prasiklus ada banyak sekali catatan sikap yang peneliti rasa memang harus segera diberikan penangan dan solusi terbaik. Sikap-sikap tersebut erat hubungannya dengan sikap toleransi antar sesama peserta didik. Melihat hal tersebut peneliti memberikan solusi penerapan model copy the master berbantuan media film animasi dalam pembelajaran menulis cerita imajinasi pada peserta didik kelas VII D SMP Negeri 11 Semarang. Hasilnya sebanyak 7 peserta didik atau $21.8 \%$ menjawab cukup, terkait penerapan sikap toleransi setelah pembelajaran dengan model copy the master, untuk sisanya sebanyak $78.1 \%$ lainnya menjawab YA. Selanjutnya sebanyak 6 peserta didik atau $15.3 \%$ mengatakan cukup mengerti pentingnya toleransi setelah pembelajaran menulis cerita imajinasi dengan model copy the master dan sebanyak $84.3 \%$ menjawab setuju. Kemudian sebanyak 3 peserta didik 9.3\% menjawab bahwa toleransi antar teman cukup menyenangkan dan sisanya 90.6\% menjawab ya menyenangkan. Terakhir sebanyak 
5 peserta didik $15.6 \%$ menjawab cukup terkait toleransi dalam pembelajaran dan sisanya $84.3 \%$ menjawab ya setuju. Sisanya secara $100 \%$ peserta didik menjawab setuju terkait pentingnya toleransi di terapkan pertemanan dan dalam hal agama.

Pada siklus I terkait perubahan sikap peserta didik memang cukup meningkat dan berubah ke arah yang positif. Beberapa peserta didik yang awalnya sulit untuk dinasihati dan suka mendiskriminasikan teman, pada siklus I sudah menunjukkan bahwa dia dapat berubah menjadi lebih baik. Namun tidak langsung berhenti pada siklus I, pada siklus II peneliti masih tetap melakukan pemantauan sikap peserta didik, fungsinya untuk benar-benar meyakinkankan bahwa peserta didik secara alamiah mengerti arti penting dan menerapkan toleransi dalam proses pembelajaran utamanya, serta dalam lingkup pertemanan dan agama.

Pada siklus II, pembelajaran menulis cerita imajinasi dengan model copy the master berbantuan media film animasi menghasilkan data bahwa setelah dua kali mendapatkan pembelajaran menulis cerita imajinasi dengan cara mengadaptasi cerita melalui film animasi yang ditayangkan peserta didik menerapkan toleransi dalam pembelajaran, yang pada mulanya siklus I ada sebanyak 7 peserta didik yang menjawab cukup pada siklus II ini berkurang drastis hanya ada 1 peserta didik yang menjawab cukup menerapkan toleransi sebanyak 31 lainya atau sebesar $96.81 \%$ menjawab dengan mantap ya. Demikian halnya dengan pentingnya nilai toleransi bila pada siklus I ada sejumlah 6 peserta didik yang menjawab cukup pada siklus II berkurang menjadi 0 sehingga persentasenya bisa mencapai $100 \%$. Selanjutnya terkait dengan toleransi antar teman menyenangkan, yang pada siklus I ada sejumlah 3 peserta didik yang menjawab cukup, pada siklus II menjadi 0 yang menjawab cukup, yang berarti $100 \%$ peserta didik menganggap bahwa toleransi antar teman itu benar-benar menyenangkan.

Berdasarkan pada hasil peresentase yang bergerak ke arah positif jelas sekali bahwa adanya peningkatan sikap peserta didik dari prasiklus ke siklus I dan menjadi semakin mantap untuk menerapkan toleransi pada siklus II. Hal tersebut juga dibuktikan dengan catatan peneliti terkait sikap peserta didik yang awalnya banyak sekali hal-hal yang harus diperbaiki pada prasiklus, menjadi semakin minim catatannya pada siklus I dan hampir catatan positif semua terkait sikap peserta didik pada siklus II. Hal ini menunjukka bahwa penerapan model Copy the Master berbantua media film animasi pada pembelajaran menulis cerita imajinasi dapat meningkatkan sikap toleransi antar peserta didik dalam aspek pembelajaran, pertemanan dan aspek agama.

\section{PENUTUP}

Penelitian tindakan kelas berhasil memberikan perubahan positif bagi peserta didik dan juga guru pengampu mata pelajaran bahasa Indonesia. Hal tersebut didasarkan pada hasil penelitian "Peningkatan Keterampilan Menulis Teks Cerita Imajinasi Bermuatan Nilai Toleransi Bagi Peserta Didik Kelas VII D". Penelitian berlangsung sepanjang 2 siklus, melalui 2 siklus tersebut, dapat terlihat adanya peningkatan yang signifikan pada proses pembelajaran, hasil belajar berupa keterampilan menulis cerita imajinasi bermuatan nilai toleransi, dan perubahan sikap intoleran antar peserta didik menjadi lebih paham dan mengerti serta menerapkan nilai toleransi dalam pembelajaran, pertemanan maupun dalam aspek agama.

Peningkatan proses pembelajaran dapat dilihat dari hasil observasi peneliti dan pendidik, hasil wawancara, hasil lembar angket, dan catatan lapangan peneliti yang memuat berbagai aspek. Peningkatan proses pembelajaran tersebut diukur pada saat prasiklus, siklus I, dan siklus II. Hal yang dapat dilihat secara signifikan yaitu meningkatnya fokus atau perhatian peserta didik ketika guru memberikan penjelasan, penghargaan dan rasa saling peduli ketika ada teman yang maju, rasa saling menghormati sesama pemeluk agama, dan rasa toleransi dalam hal pergaulan. Proses pembelajaran pada prasiklus menggunakan model pembelajaran dari pendidik, tepatnya menggunakan metode ceramah dan penugasan. Pada proses pembelajaran prasiklus, kondisi kelas tidak kondusif, banyak peserta didik yang ramai dan berbicara sendiri dengan temannya. Saat pendidik menjelaskan banyak yang tidak memperhatikan. Hal tersebut dilandasi karena kebosanan peserta didik dengan cara pembelajaran yang monoton. Pada kegiatan pembelajaran siklus I dan II, dilakukan oleh peneliti menggunakan model copy the master berbantuan media film animasi. Pada proses pembelajaran siklus I dan siklus II, peserta didik sudah dapat dikendalikan, kondisi kelas juga semakin kondusif tiap harinya. Hal tersebut karena pada awal pembelajaran, peneliti selalu menghadirkan hal yang berbeda untuk menarik perhatian peserta didik. Hasilnya kelas menjadi kondusif dan kegiatan pembelajaran berlangsung lebih nyaman serta terkendali.

Sejalan dengan itu, peningkatan juga terjadi pada hasil belajar peserta didik yang berwujud teks cerita imajinasi bermuatan nilai toleransi. 
Nilai rata-rata menulis cerita imajinasi bermuatan nilai toleransi pada peserta didik terus mengalami peningkatan semenjak prasiklus, siklus I, dan siklus II. Begitu pun dengan persentase ketuntasan peserta didik dalam menulis cerita imajinasi bermuatan nilai toleransi. Pada prasiklus, rata-rata nilai menulis peserta didik hanya mencapai nilai 24.6 dengan persentase ketuntasan $0 \%$, Peningkatan signifikan telah terlihat sejak siklus I dengan nilai rata-rata siklus I sudah mencapai 86.88 dengan persentase ketuntasan $100 \%$. Peningkatan kembali terjadi pada siklus II dengan nilai menulis cerita imajinasi bermuatan nilai toleransi peserta didik terjadi pada siklus II dengan nilai rata-rata sebesar 90.1 yang diikuti persentase ketuntasan sempurna $100 \%$.

Sementara itu, perubahan sikap intoleran peserta didik turut diperhatikan oleh peneliti dan pendidik bahasa Indonesia semenjak prasiklus, siklus I, dan siklus II. Pada prasiklus sikap intoleran peserta didik sangat kental sehingga membuat suasana kelas tidak terasa kondusif dan nyaman. Kiat untuk mengubah sikap peserta didik dilakukan selama siklus I dan siklus II berlangsung, dengan menerapkan model copy the master berbantuan media film animasi. Tentu pada film animasi yang ditayangkan mengandung ajaranajaran toleransi yang baik, misal dalam hal sederhana toleransi berpendapat, toleransi dalam pertemanan dan toleransi untuk saling memaafkan. Bukan hanya itu, pada pertemuan kedua dan ketiga siklus I peserta didik sengaja dibentuk berkelompok untuk menyelesaikan tugas dari peneliti tujannya agar mereka dapat saling berinteraksi dan memahami satu sama lain dalam kelompok. Bagaimana cara mereka menyikapi perbedaan pendapat yang ada dalam kelompok, bagaimana mereka bersikap bila ada yang ingin memberikan kontribusi berlebih dan lain sebagainya. Sikap peserta didik perlahan mulai menunjukkan perubahan, hingga akhirnya sikap peserta didik tidak lagi intoleran secara signifikan yang mulai terlihat jelas pada siklus I. Peserta didik sudah mengerti pentingnya toleransi untuk memberikan kenyamanan dan kekondusifan dalam pembelajaran sehingga kehidupan sehari-hari pun mereka dapat menjadi makhluk sosial yang baik untuk sesamanya.

\section{DAFTAR PUSTAKA}

Arifa, A., \& Doyin, M. (2015). Pengembangan Buku Panduan Menyusun Teks Cerpen Dengan Menggunakan Teknik Urai Unsur Intrinsik Bagi Siswa Kelas VII Sekolah Menengah Pertama (Smp). Jurnal Pendidikan Bahasa Dan Sastra Indonesia, 4(1), 1-6.
Astuti, Y. W., \& Mustadi, A. (2014). Effects Of The Use Of Animation Film Media On The Narrative Text Writing Skill Of Grade V Students Of Ess. Jurnal Prima Edukasia, 2(2), 250-262.

Hakim, L. (2012). Model Integrasi Pendidikan Anti Korupsi. Jurnal Pendidikan Agama Islam, 10(2), 141-156.

Kapitan, Y. J., Harsiati, T., \& Basuki, I. A. (2018). Pengembangan Bahan Ajar Menulis Teks Cerita Fantasi Bermuatan Nilai Pendidikan Karakter di Kelas VII. Jurnal Pendidikan, 3, 100-106.

Kurnianingtyas, E. (2015). Penerapan Teknik Copy The Master Untuk Meningkatkan Keterampilan Menulis Cerpen Siswa Kelas VII-B Mts. Darun Najah Petahunan Lumajang. NOSI, 2(8), 30-40.

Mulyatiningsih, E. (2010). The Analysis of Character Education Models for Children, Adolescents and Adults. Ft Uny, 2(1), 1-18.

Najmi, F. (2015). Learning Implementation Of Fantasy Stories Text In The Seventh F Of Smp Negeri 8 Yogyakarta. Bahasa Dan Sastra Indonesia, 1(1), 250-350. Retrieved from Perencanaan, Pelaksanaan, Penilaian Teks Cerita Fantasi

Nurgiyantoro, B. (2009). Penilaian Pengajaran Bahasa dan Sastra. Edisi Ketiga. Jurnal Pendidikan Bahasa Dan Sastera, 2(2), 3.

Nursayyidah, S. R. (2015). Penerapan Teknik Copy The Master Berbasisis Perkembangan Intelektual Dalam Pembelajaran MenulisTeks Berita Pada Siswa Kelas VIII. Jurnal Pendidikan Bahasa Dan Sastera, 2(1), 1-8.

Putri, D. (2017). Peningkatan Keterampilan Menulis Cerita Pendek dengan Menggunakan Teknik Copy The Master Pada Mahasiswa Pendidikan Bahasa dan Sastra Indonesia STKIP Rokania. Jurnal Pendidikan Karakter, II(1), 30-47.

Rahmattullah, M. (2011). media. Jurnal Penelitian Pendidikan, 1(1), 178-186.

Ratni, O. L. (2016). Pengaruh Model Pembelajaran Imajinatif terhadap Keterampilan Menulis Cerita Anak di Kelas IV Sdn 15 Pontianak. Jurnal Pendidikan Dan Pembelajaran, 6(9).

Sibarani, O. B. (2015). Penerapan Proses Kognitif dan Cognitive Blocking. Jurnal Bahasa, 2(1), 132142.

T. S., Y. (2006). Pendidikan Anti Korupsi di Sekolah, Perlukah? Humaniora, 3(2), 1-7.

Widuroyekti, B. (2016). Pemanfaatan Cerita Anak 
Sebagai Alternatif Bahan Pembelajaran Apresiasi Sastra di Sekolah Dasar. Kependidikan, 3(1412 - 2952), 1-76. Retrieved from https:// s3.amazonaws.com/academia.edu.documents/42784079/JURNAL-PORTAL-3.pd $\mathrm{f}$ ?AWSAccessKeyId=AKIAIWOWYYGZ 2Y53UL3A\&Expires $=1556196954 \&$ Signa ture $=$ JoFAHrofKT7HQQJeibQQiRJkqng $\% 3 \mathrm{D} \&$ response-content-disposition=inline
$\% 3 B$ filename $\% 3$ DJURNAL_PORTAL 3. pdf\#page $=41$

Zurita, I., Effendi, T. H., \& Catri, T. A. (2017). Pengaruh Teknik Copy The Master Terhadap Keterampilan Menulis Teks Prosedur Siswa Kelas VII Mtsn Lubuk Buaya Kota Padang. Pendidikan Bahasa Dan Sastra Indonesia, 1(7), 175-182. 